\title{
Gender Differences in the Impact of Child Sexual Abuse on Alexithymia, Dissociation and Self
}

\author{
Peter Paul Moormann'1, Francine Albach', \\ Bob Bermond2, Annemieke van Dijke4, Jakob de Jong1, \\ Jaco Wineke ${ }^{1}$, Kalliopi Metta ${ }^{1}$ and Argyro Karanafti ${ }^{1}$ \\ ${ }^{1}$ Leiden University, \\ 2 University of Amsterdam, \\ ${ }^{3}$ Private Psychotherapeutic Center in Amsterdam \\ ${ }^{4}$ Delta Psychiatric Center, \\ The Netherlands
}

\section{Introduction}

Childhood Sexual Abuse (CSA) is a topic with a long history in both psychiatry and psychology. In fact grand old theories such as Freud's Psychodynamic Theory, its predecessor the Seduction Theory, and Janet's Dissociation Theory were based on the investigation of hysteria in cases of sexual abuse. In those days sexual abuse primarily concerned women. The recent attention in the media for male victims of sexual abuse, particularly young boys having been molested by Catholic priests and very young children having been abused in crèches and being exposed on the secret internet websites of paedophile networks, has led after the second feministic wave to a renewed interest in CSA and its adverse effects. Therefore in the forthcoming research the following questions will be raised:

What is the impact of severe CSA on alexithymia, dissociation and self?

Do female subjects differ from male subjects on the impact of CSA?

In the theoretical part first the issue of credibility in relation to gender will be briefly discussed in a historical perspective. Sexual abuse is a criminal act and the credibility of a victim who accuses a perpetrator of sexual abuse has always been, and still is, a delicate subject in court. After having dealt with the literature on the impact of CSA upon alexithymia, dissociation and self the theoretical part will be concluded with some general findings on how the sexes cope with CSA, as no systematic studies have been conducted yet on gender differences in alexithymia, dissociation and self in CSA.

\section{Gender and the issue of credibility}

In contrast with female victims of sexual abuse from the $19^{\text {th }}$ century on up to the recent case of DSK (Dominique Strauss-Kahn) the credibility of war victims in the 1st World War was 
not an issue of importance. There were no doubts on what had happened to them, because quite often there was a whole regiment of witnesses. However doubts existed on whether soldiers were really ill as they displayed a wide array of behavior that nowadays would be classified as conversion hysteria. Since Horowitz's (1976) introduction of the Theory of Stress Response Syndromes there has been a growing interest in the effects of exposure to traumatic events, and the systematic investigation of complaints reported by male survivors of war resulted in the description of Post Traumatic Stress Disorder (PTSD). However it took much longer before reports of CSA in women were taken seriously. Already from the end of the $19^{\text {th }}$ century reports on female sexual abuse were considered to be false sexual allegations ('sexuelle Falschanschuldigungen' in German, see Birnbaum, 1915) and in France it was called the phenomenon of the 'accusatrices hystériques' (see Garnier, 1903). This tradition was kept alive when Psychoanalysis dominated the academic scene, as accounts of sexual abuse were simply treated as 'Oedipal Fantasies'. Hence, the term 'pseudologia phantastica' is firmly rooted in the history of CSA. Only quite recently, during the second feministic wave in the last two decades of the 20ieth century it was acknowledged by academic psychology that CSA really occurs and that the effects can be traumatic enough to meet the criteria of PTSD (see Finkelhor \& Browne, 1985; Albach \& Everaerd, 1992; Albach, 1993; Zeitlin et al., 1993). However, the battle had not been won yet. In particular women with repressed memories of sexual abuse (those who experienced episodes of inability to recall the event) had a long history of being treated with great suspicion (Albach et al., 1996). The last revival of this skeptic tradition (the abuse did not really happen) evolved after 1990 and was based on the idea of false or implanted memories created under hypnosis in psychotherapy (Ceci \& Loftus, 1994; Loftus, 1993, 1997). The foregoing on credibility illustrates well that war victims and CSA women have in common that both were accused of pretending or lying, however on different grounds. Soldiers were accused of lying about their illness; by malingering they tried to avoid being sent back to the deadly frontlines, while CSA women were accused of lying about what had happened to them, e.g. about the sexual abuse as an excuse or explanation for their current miserable psychological state (Crombach \& Merkelbach, 1996).

Until recently studies on CSA were almost uniquely based on women. Empirical studies on the impact of CSA in male victims were beyond the scope of the feministic perspective. However the numerous recent reports of male CSA victims within the Roman Catholic Church in the media inevitably had to lead to a shift of focus in this female-only approach. Comparisons between female and male victims are a logical consequence. It is striking that in all female cases fantasy-proneness or high suggestibility is used as a personality trait causing women to report such lies or false memories, while in the recent cases of male sexual abuse, in the media hardly any doubts on the credibility of the reports of the male victims has been expressed. It might be that under enormous political pressure from the media, the already badly wounded Catholic Church had no other way-out than to stand in a white sheet, and the priests, some of whom are still alive, lost their status of inviolability and as a consequence had to confess their misconduct. Although it cannot be denied that in some cases women do lie about or simulate sexual abuse (see the literature on false memories, for instance Yapko, 1994), as by the way happens with many other events in court, it remains remarkable that even the second feministic wave has not been robust enough to prevent women from being accused of hysteria, making up stories or lying about sexual abuse, while the credibility of men reporting being molested by 
priests apparently is not an issue of serious debate. If this line of reasoning is true then, even in the $21^{\text {st }}$ century the impact of sexual abuse for women is far greater than for men, as the credibility of women is even nowadays under debate. They are still considered to be liars, fantasy-prone, too emotional and therefore their credibility is dubious. The recent case of 'DSK' seems to confirm that 'pseudologia phantastica' still rules in court. This almost archetypal denigrated attitude towards women might also explain the negative self, commonly reported by victimized women (Russell, 1986).

\section{Impact of CSA on alexithymia, dissociation, and self}

\subsection{Impact of CSA on alexithymia}

Alexithymia has been introduced by Sifneos and literally means 'wordless affect', indicating the incapacity to recognize and express the emotional experience in verbal forms. Sifneos (1973) came up with this term after observing that a great amount of patients suffering from psychosomatic complaints were not able to verbally express and describe their affective experience and also distinguish it from bodily sensations; such difficulty constituted only a part of a wider cluster of cognitive and affective characteristics also including restricted imagination characterized by a marked paucity of fantasy and a literal, utilitarian cognitive style that is externally oriented. This cluster of characteristics constitutes a major obstacle in the process of treatment and contributes to the failure of response to therapy (Sifneos, 1975).

Krystal (1988) was probably the first to emphasize that alexithymia is one of the sequelae of traumatic experiences. From research data evidence exists for the idea that psycho-traumata can indeed induce alexithymia (Hyer et al., 1990; Thomas et al., 1992; Berenbaum \& James, 1994; Zlotnick, et al., 2001; Frewen et al., 2008). Victims of both rape (Zeitlin et al., 1993) and CSA (Albach \& Everaerd, 1992; Berenbaum, 1996; Cloitre et al., 1997; Moormann et al, 1997; Sher \& Twaite, 1999; Bermond et al., 2008) are known to suffer from alexithymia. Milder forms of CSA are not always associated with alexithymia (Paivio \& McCulloch, 2004; Kooiman et al., 2004; Modestine, Furrer, \& Malti, 2005).

\subsection{Impact of CSA on dissociation}

Pierre Janet (1889) was the first to describe the concept of dissociation as a result of his extensive work with hysteric patients. He referred to dissociation as a process involving the breaking down of those structures of the mind that are interconnected within a single stream of consciousness. More specifically, the mind is constructed by separate compartments constituting from emotions, cognitions and actions; however as a consequence of trauma, stress or weakness the breakdown of this stream of consciousness may occur as a result of the splitting of one of those structures from the rest. Such alternations then in those structures inhibit the normal integration of information to the components that are involved and induce alternations in memory and identity, promoting in such way the development of different kinds of dissociative disorders, depending on the severity of the symptoms (Putnam, 1993).

Dissociation, one of the adverse effects of CSA (Chu \& Dill, 1990; Ensink, 1992; Kirby et al., 1999; Kisiel \& Lyons, 2001 ), is often studied together with alexithymia, and both constructs 
are considered to contribute to the enhancement of emotional disengagement from the traumatic event (Zlotnick et al., 1996; Irwin \& Melbin-Helberg, 1997; Grabe, et al., 2000; Elzinga, et al. (2002); Moormann et al., 2004).

\subsection{Impact of CSA on self}

The first psychologist to develop a theory of self was William James (1890). According to his theory self consists of four integrated parts: the "spiritual self" (what we most truly seem to be), the "social self" (individuals and groups about whose opinion we care), the "material self" (material possession we see as part of us) and the "bodily self" (body image). These four selves combine to constitute each person's view of himself and his self-concept. Furthermore, James developed his theory as to the position a person holds in the world, which determines his self-esteem depending on his success or failure. Our perceptions of where we see ourselves standing in relation to others whose skills and abilities are similar to our own determine our inner feeling of self-worth.

Regarding self and CSA, Janoff-Bulman and Frieze (1983) argue that the trauma of victimization activates negative self-images. Victims see themselves as weak, helpless, needy, frightened and out of control. They are also apt to experience a sense of deviance. Therefore, effective coping with victimization requires not only coming to terms with a world in which bad experiences happen to one-self, but also restoring a damaged selfimage. Low self-regard, commonly found among victims of repeated sexual abuse is emphasized by Russell (1986) as follows (p. 190):

"Women who place or find themselves in risky situations in the predatory world in which we live are quite likely to be raped. This does not, of course, mean they want to be raped, or that they don't mind it. It means that their self-esteem may be so damaged that they don't feel they deserve their own loving self-protection. This, in turn, can result in repeated victimizations, each one of which can undermine a women's self-esteem still further".

A survey done by Russell and co-workers (1986) shows that re-victimization is most of the time neither a one-time experience nor a rare occurrence, but more often extremely common. The kind of behavior displayed by the victim might be the reason why revictimization in children happens so often. Clinical accounts indicate that sexual offenders who don't know about a child's previous victimization may be experts at picking up cues of vulnerability, such as low self-image or a strong but unsatisfied need for affection and attention. Finkelhor and Browne (1985) have developed a theoretical model for analyzing child sexual abuse in terms of four trauma-causing factors: traumatic sexualization (i.e., a child's sexuality is shaped in a developmentally inappropriate and interpersonally dysfunctional fashion as a result of sexual abuse), stigmatization (i.e., negative connotations - e.g., badness, shame, and guilt, that are communicated to the child around the experiences and that then become incorporated into the child's self-image), betrayal (i.e., children discover that someone on whom they were vitally dependent has caused them harm), and powerlessness (i.e. the child's will, desires, and sense of efficacy are continually contravened). Finkelhor and Browne refer to these factors as traumagenic dynamics, and suggest that these factors alter children's cognitive and emotional orientation to the world, and create trauma by distorting children's self-concept, worldview, and affective capacities. 


\subsection{Hypotheses}

Victims of CSA will display:

a. A high prevalence of alexithymia.

b. High dissociation scores, indicative of Dissociative Identity Disorder (DID).

c. A negative self.

\section{Explorative part: Gender differences}

Gender differences in alexithymia, dissociation, and self have been published in populations other than CSA. The general picture reveals higher alexithymia scores for men on the BVAQ (Vorst \& Bermond, 2001). However, reports using the TAS, failed to demonstrate such gender differences in alexithymia (Parker, Taylor \& Bagby, 1989). While, in general men were found to be more alexithymic, women tended to be more vulnerable to dissociation (Coons, 1996; Ross, 1996). Many researchers though reported surpassing scores for males on the frequency of dissociative disorders in various populations including children, adolescents, criminal offenders and forensic patients are reported as well (Kluft, 1996; Putnam et al., 1996). These inconclusive findings can be attributed to methodological problems, such as comparing outcomes from classification systems with outcomes from questionnaires, different populations, and different instruments. For self gender outcomes are even more confusing because researchers have a tendency to make a distinction between an interdependent and an independent self-construal. The social, institutional, and cultural environment of the United States for instance promotes development of independence and autonomy in men and interdependence and relatedness in women (Bakan, 1966; Maccoby, 1990; Markus \& Oyserman, 1989). Therefore the outcome of the comparison is dependent upon the self-construal chosen which hampers the making of absolute statements on gender differences.

The comparatively few studies that did investigate both male and female CSA victims seem to indicate that the variety of maladaptive psychological behaviours and psychiatric disorders associated with CSA are expressed differently in boys and girls (Walker et al., 2004). In general, girls manifest a tendency to internalizing behaviours (Butler \& NolenHoeksema, 1994). Boys on the other hand have been found to display a coping style in response to CSA characterized by more externalizing behaviours (Garnefski \& Arends, 1998; Kuhn et al., 1998). The different expressions of the impact of CSA on gender may be partly explained by the influence of CSA on gender identity. Male victims seem to become more commonly confused about their sexual identity and orientation in heterosexual relationships (Tzeng \& Schwarzin, 1990). Such confusion stems from any type of perceived responsiveness to the incident taking place from the same sex abuser and may lead to the assumption that the masculinity of the victim has been compromised (Moody, 1999). In such cases boys may be more prone to acting out aggression and engaging in delinquent activities in an effort to compensate for and re-establish their perceived loss of masculinity (Rogers \& Terry, 1984). Girls on the other hand tend to display a more damaged self esteem and self blame, not only because of their tendency to ruminate, but also because in many cases they are often held responsible for the abuse by suggesting that girls seduced and encouraged the perpetrator (Carmen et al., 1984; Herman, 1981; Kohn 1987), with shame and guilt feelings as a consequence. Additionally, fear and distress enhance a maladaptive vulnerability that 
stems from their perception that the world is a dangerous and threatening place (Feiring et al., 1999). The above seems to be confirmed by case studies, where male victims of sexual abuse were found to have low self-esteem as well (Myers, 1989). Expressions were as being flawed, and shame and guilt for participating in the sexual activities were reported as well, which later may become personality traits. Hunter (1990) reports significantly lower selfesteem scores for male victims of sexual abuse as opposed to non-victims. Dhaliwal et al. (1996) report reduced sexual self-esteem as a consequence of sexual abuse.

In contrast with the above studies where gender comparisons are more relative than absolute, in the present research possible differences in symptom reporting between the sexes will be tested using the same constructs and the same instruments.

\section{Method}

\subsection{Sample}

Seventy-five subjects, reporting CSA volunteered in our research. The total group consisted of seventeen men and fifty-eight women, ranging from sixteen to sixty-one years of age (M age males $=37.31 ; \mathrm{M}$ age females $=37.83$ ) .

\subsection{Procedure}

Respondents were recruited through newspaper announcements and through contact persons, working in CSA self-help groups supervised by clinical psychologists, where group members were encouraged to both share and cope with their traumatic past by receiving support and understanding from their fellow group members. It should be noted that it was much harder to find male than female subjects. Furthermore the data of the male subjects were collected at another location and time. Hence the sessions consisted of either males only or females only. Before entering the first session a test battery was administered to each gender group consisting of a Checklist for CSA Characteristics, the BVAQ, the DES, and the LSQ.

\subsection{Instruments}

Checklist for Childhood Sexual Abuse Characteristics, specially developed for this occasion, mainly based on the results and insights derived from in-depth interviews taken by Ensink (1992) and Albach (1993) for their PhD research.

The checklist contains 8 categories:

1) Perpetrator (a. father; b. brother or sister; c. other relative (grandfather, uncle, etc.); $d$. family friend; e. stranger; f. familiar persons other than relatives or family friends); 2) Onset before the age of 10; 3) Duration; 4) Frequency; 5) Assault (a. sexual harassment; b. masturbation; c. attempted penetration; d. penetration; e. fellatio; f. anal penetration; 6) Coercion (a. position of power; b. misleading; c. presents; d. threatening; 7) Enforcing secrecy (a. shame on you; b. emotional pressure; c. physical violence); 8) Memory recovery (a. having experienced an episode of inability to recall the traumatic event; $b$. number of years)

If otherwise mentioned all items were coded in a yes/no format. In the category perpetrator for instance the number of perpetrators could be indicated in the subcategory 
strangers. Duration related to the numbers of years the abuse had lasted and frequency related to how many times a week the abuse had taken place. In the category coercion misleading meant that the child was told it was perfectly normal for children to be involved in the kind of sexual activities the perpetrator demanded. Giving presents to the victims supposedly was a strategy to consolidate the bond between perpetrator and child and thereby avoiding betrayal. Threatening meant that the child would no longer benefit from all kind of privileges if it refused to cooperate. Giving the child the idea that he/she was responsible for the abuse by seducing the perpetrator was applied to ensure the abuse was kept a secret. The child was bad and should be ashamed. Exerting emotional pressure happened when the perpetrator convinced the child that he acted out of love and that revealing "our secret" would make the perpetrator very sad and would ruin his life. Physical pressure was another way of preventing the child from revealing the abuse. Finally memory recovery was investigated by asking the subjects whether he/she had ever experienced an episode of inability to recall the traumatic events and if so how many years this period lasted.

Bermond-Vorst Alexithymia Questionnaire (BVAQ, Bermond \& Vorst, 1993), consisting of five subscales (Vorst \& Bermond, 2001) which relate to a reduced ability to: a) verbalize emotional experiences (Verbalizing), b) differentiate between emotional feelings (Identifying), c) reflect upon emotions (Analyzing), d) fantasize (Fantasizing), and e) experience emotional feelings (Emotionalizing).

Reliability and validity of the BVAQ are good (Vorst \& Bermond, 2001; Bermond et al., 2007). Assessing the prevalence of alexithymia is based on impairment of the cognitive component (sum total of reduced Verbalizing, Identifying, and Analyzing), as an impaired cognitive component (belonging to Type I and Type II alexithymia) appeared to be related to a broad range of psychological disorders (Moormann et al., 2008; see also the 2007 publication of Bailey \& Henry for the relation between Type I \& II alexithymia and somatization), while an impaired affective component (sum total of reduced Emotionalizing \& Fantasizing) primarily related to activities where expressive behaviour and creative imagination were hampered. For both alexithymia components scores $\geq$ percentile 70 were used as an indication of impairment while scores $\leq$ percentile 30 were used as an indication of unimpairement. In the Moormann et al. study of 2008 the cut-off scores for the alexithymia types (based on a student population of 354 subjects) were computed as follows: raw scores $\geq 54.0$ related to an impaired cognitive component while raw scores $\leq 43.0$ related to an unimpaired cognitive component. Regarding the affective component raw scores $\geq 42.0$ related to an impaired affective, while raw scores $\leq 34.0$ related to an unimpaired affective component. Using the above cut-off scores for an impaired cognitive BVAQ component as an indication of the prevalence of alexithymia resulted in an incidence of alexithymia of $20.4 \%$ in the Netherlands (Moormann et al., 2008) and of 18.2\% in Australia (Bailey \& Henry, 2007). On the basis of an albeit small clinical sample of 39, Taylor et al. (1997) suggest a cutoff value of 61 and above on the Toronto Alexithymia Scale (TAS-20). Despite the different instrument for alexithymia the statistics given in Finland (21.0\%; Honkolampi et al., 2000), using these TAS-20 cut-off scores, are practically the same as the statistics obtained with the BVAQ in Australia and The Netherlands. Older studies using a cut-off on the earlier 26-item TAS have reported rates of 23\% for a normal group in France (Loas et al., 1995) and 18.8\% in Canada (Parker et al., 1989). Hence, the cut-off scores used in the present research seem a fair indication for the prevalence of alexithymia. 
Dissociative Experiences Scale (DES - Bernstein \& Putnam, 1986), a widely used self-report scale, containing 28 items, using a visual analogue scale (from 0-100). A Dutch adaptation was administered, consisting of the 3 subscales, as defined by Ross et al. (1995): a) Absorption-imaginative involvement ("So involved in fantasy that it seems real"), b) Activities of dissociated states ("Finding oneself in a place, but unaware how one got there"), and c) Depersonalization / Derealization ("Not recognizing one's reflection in a mirror; Other people and objects do not seem real")

Summing up all the scores and then dividing them by 28 results in the average DES score. The test retest reliability is good (0.84-0.96) and effectively differentiates patients with Dissociation from other psychiatric groups (Bernstein \& Putnam, 1986). The DES can be used as a screening instrument for Dissociative Identity Disorder (DID). However semistructured interviews are needed for a reliable diagnosis. Several cut-off values are used, ranging from 20 (Ross et al., 1991) to 31.3 (Bernstein \& Putnam, 1986). In The Netherlands the DES cut-off scores were validated using the outcomes from clinical diagnostic interviews (Boon \& Draijer, 1993), which resulted in an optimal cut-off score of 25 for the screening of DID. The mean DES scores in normal populations vary from 3.7 to 7.8 , while scores of a group of a-select psychiatric patients vary from 14.6 to 17.0 (in Boon \& Draijer, 1993).

Leiden Self Concept Questionnaire (LSQ; Moormann \& Duikers, 1984). The items relate to intellectual functioning, social functioning, physical appearance and self-efficacy. It consists of 27 items, first formulated in the present tense (present self), then in the past tense (past self), and finally in the future tense (future self). Only the present self will be discussed in our study. The Cronbach alphas are based on the 1989 publication by Moormann et al., and are given for the sexes separately (male: $\langle=.89$; female: $\langle=.87$ ). Scores $\leq$ percentile 30 is considered to be indicative of a low self (cut-off score of $\leq 103$ for a student population (based on the data of the Moormann et al. study of 2008), cut-off score of $\leq 80$ for male and $\leq$ 63 for female poly hard drug addicts (based on the data of the Moormann et al. study of 1989, and the Bauer et al. study of 1992), and cut-off scores $\leq 98$ for the elderly (74-98 years of age), discussed in the data of the Moormann, et al. study of 1997.

\subsection{Statistical analyses}

First Independent-Samples $t$ Tests will be run on all abuse characteristics (dependent variable) to identify whether the sexes (independent variable) differ on these variables. If so then in all analyses where means are compared it will be controlled for those abuse characteristics where sexes differ.

Regarding Hypothesis $\mathbf{1}$ it was decided to use cut-off scores to identify the prevalence of alexithymia, dissociation and low self in the CSA group.

Gender differences will be tested by again performing Independent-Samples $t$ Tests with gender as independent and alexithymia, dissociation and self as dependent variable.

\section{Results}

\subsection{Gender differences in abuse characteristics and age}

The results are given in Table 1 and demonstrate that the sexes didn't differ significantly neither on any of the abuse characteristics nor on age. However there was one trend on anal penetration that was more prominent in male than in female subjects. 
Regarding the category perpetrator only t-tests where the father had been the perpetrator ( $29 \%$ for males, $40 \%$ for females) could be computed as in all other cases one of the groups contained empty cells: $18 \%$ of the males reported abuse by brother or sister, none of the females; No males reported abuse by other relatives (grandfather, uncle, etc.), while $24 \%$ of the females did; No males reported abuse by a family friend, while $6 \%$ of the females did; No males reported abuse by strangers, while the average numbers of abusive strangers was 1.12 for females; however $47 \%$ of the males reported abuse by people they knew other than relatives or a family friend, whereas none of the females did.

\begin{tabular}{|c|c|c|c|c|c|c|c|c|}
\hline \multirow{2}{*}{$\begin{array}{c}\text { Abuse } \\
\text { Characteristics }\end{array}$} & \multicolumn{3}{|c|}{ MALE } & \multicolumn{3}{|c|}{ FEMALE } & \multirow[b]{2}{*}{ t-test (2-tailed) } & \multirow[b]{2}{*}{ Sig } \\
\hline & $\mathbf{N}$ & $\mathbf{M}$ & SD & $\mathbf{N}$ & $\mathbf{M}$ & SD & & \\
\hline 1. FATHERperpetrator & 17 & 0.29 & 0.47 & 50 & 0.40 & 0.50 & $t(1,65)=-0.77$ & $\mathrm{~ns}$ \\
\hline $2 . O N S E T<10$ & 17 & 0.71 & 0.47 & 49 & 0.78 & 0.42 & $t(1,64)=-0.57$ & ns \\
\hline 3. DURATION & 17 & 3.12 & 1.36 & 45 & 4.62 & 4.13 & $t(1,60)=-1.47$ & ns \\
\hline 4. FREQUENCY & 17 & 3.82 & 1.47 & 40 & 4.35 & 1.25 & $t(1,55)=-1.38$ & ns \\
\hline \multicolumn{9}{|l|}{ 5. ASSAULT } \\
\hline a. sexual harassment & 17 & 0.94 & 0.24 & 47 & 1.00 & 0.00 & $t(1,16)=-1.00$ & ns \\
\hline b. masturbation & 17 & 0.76 & 0.44 & 44 & 0.70 & 0.46 & $t(1,59)=0.46$ & ns \\
\hline c. att. penetration & 17 & 0.41 & 0.51 & 44 & 0.66 & 0.48 & $t(1,59)=-1.78$ & ns \\
\hline d. penetration & 17 & 0.47 & 0.51 & 45 & 0.64 & 0.48 & $t(1,60)=-1.24$ & ns \\
\hline e. fellatio & 17 & 0.65 & 0.49 & 45 & 0.47 & 0.50 & $t(1,60)=1.26$ & ns \\
\hline f. anal penetration & 17 & 0.41 & 0.51 & 45 & 0.16 & 0.37 & $t(1,22.61)=1.90$ & .07 \\
\hline \multicolumn{9}{|l|}{ 6. COERCION } \\
\hline a. position of power & 17 & 0.76 & 0.44 & 49 & 0.92 & 0.28 & $t(1,20.62)=-1.4$ & ns \\
\hline b. misleading & 17 & 0.71 & 0.47 & 49 & 0.67 & 0.47 & $t(1,64)=0.24$ & ns \\
\hline c. presents & 17 & 0.53 & 0.51 & 49 & 0.51 & 0.51 & $t(1,64)=0.13$ & ns \\
\hline d. threatening & 17 & 0.53 & 0.51 & 49 & 0.49 & 0.51 & $t(1,64)=0.28$ & ns \\
\hline \multicolumn{9}{|l|}{ 7. ENFOR. SECRECY } \\
\hline a. shame & 17 & 0.94 & 0.24 & 47 & 0.91 & 0.28 & $t(1,62)=0.34$ & ns \\
\hline b. emotional pressure & 17 & 0.71 & 0.47 & 47 & 0.72 & 0.45 & $t(1,62)=-0.14$ & ns \\
\hline c. physical violence & 17 & 0.35 & 0.49 & 48 & 0.35 & 0.48 & $t(1,63)=-0.01$ & ns \\
\hline 8. MEM RECOVERY & 17 & 0.41 & 0.51 & 46 & 0.57 & 0.50 & $t(1,61)=-1.08$ & ns \\
\hline duration MEM REC & 16 & 8.19 & 13.63 & 46 & 11.67 & 12.89 & $t(1,60)=-.92$ & ns \\
\hline$A G E$ & 16 & 37.31 & 11.36 & 52 & 37.83 & 9.73 & $t(1,66)=-0.18$ & ns \\
\hline
\end{tabular}

Table 1. Gender differences in abuse characteristics and age

Because of empty cells only the scores for the father were given in Table 1 . None of the differences reached significance. The elevated percentages suggest a severe form of CSA. 
The average abuse lasted 3-4 years (ranging from 1-30 years), and happened 3-4 times a week. Furthermore the prevalence of the various assaults (ranging from 16\% to 100\%) indicates severe abuse when considering:

a. The high incidence of coercion measures ranging from $51 \%$ to $92 \%$,

b. The moderate to very high incidence of enforcing secrecy measures ranging from $35 \%$ to $94 \%$, and

c. The considerable incidence of reported memory recovery, e.g. $41 \%$ for males and $57 \%$ for females with a mean duration of 8.19 years for males and 11.67 years for females. In one case a memory recovery had been reported after 46 years.

The finding that $71 \%$ of the males and $78 \%$ of the females reported that the abuse had started before the age of 10 suggests that we are really dealing with childhood sexual abuse.

Because neither on age nor on any abuse characteristic significant gender differences could be demonstrated, there was no further need for controlling for these variables in the upcoming statistical analyses where gender differences were tested on alexithymia, dissociation and self.

\subsection{Impact of CSA on alexithymia, dissociation and self}

Considerable evidence was found for Hypothesis 1, stating that CSA-victims display:

A high prevalence of alexithymia (e.g. scores $\geq 54.0$ on the cognitive component of the BVAQ), as $40 \%$ of the CSA subjects (see Table 1 in the next chapter by Moormann, Albach \& Bermond on alexithymia, dissociation and memory recovery) could be classified as either Type I (14\%) or Type II (26\%) alexithymia compared with the common guideline that about $1 / 5^{\text {th }}$ of the normal population is alexithymic (see Instruments for prevalence statistics).

High dissociation scores (DES/28 > 25), as the average DES scores of both male $(\mathrm{M}=25.79)$ and female $(\mathrm{M}=38.23)$ CSA respondents exceeded the optimal cut-off value of 25 (see Table 2), indicative of Dissociative Identity Disorder (DID). Regarding the incidence of severe dissociation it was found that $47 \%$ of male and $78 \%$ of the females had average DES scores $>25$

A negative Self as the average Self scores for male $(M=88.39)$ and female $(M=71.06)$ CSA respondents (see Table 2) were far below the cut-off value for students $(\mathrm{N}=1061)$ corresponding to $\leq$ percentile 30 (Mean LSQ $\leq 103$ ). Unfortunately norms for the normal population were not yet available. However compared with the elderly $(\mathrm{N}=30$; 74-98 years of age) the scores of both male and female CSA respondents were also far below the cut-off value of 98 , corresponding to values lower than percentile 25 . Compared with poly hard drug addicts, known for a negative self, the average mean self scores of both male and female CSA respondents fell in stanine 4 (for norm references see Instruments).

\subsection{Explorative part: Gender differences}

In Table 2 the statistics for this paragraph are given. 


\begin{tabular}{|l|c|c|c|c|c|l|l|}
\hline Dependent Variable & \multicolumn{3}{|c|}{ MALE } & \multicolumn{3}{|c|}{ FEMALE } & \\
\hline & $\mathbf{N}$ & $\mathbf{M}$ & SD & N & M & SD & t-tests (2-tailed) \\
\hline ALEX Total & 17 & 109.71 & 24.98 & 43 & 123.98 & 19.23 & $\mathrm{t}(1,58)=-2.38^{*}$ \\
\hline COG & 17 & 65.53 & 18.95 & 45 & 77.44 & 16.67 & $\mathrm{t}(1,60)=-2.42^{*}$ \\
\hline a. Identifying & 17 & 21.88 & 7.30 & 44 & 30.30 & 7.46 & $\mathrm{t}(1,59)=-3.97^{* * *}$ \\
\hline b. Verbalizing & 17 & 24.47 & 8.23 & 45 & 29.91 & 7.53 & $\mathrm{t}(1,60)=-2.47^{*}$ \\
\hline c. Analyzing & 17 & 19.18 & 7.59 & 44 & 18.32 & 6.40 & $\mathrm{t}(1,59)=0.45$ \\
\hline AFF & 17 & 44.18 & 9.99 & 45 & 45.60 & 8.65 & $\mathrm{t}(1,60)=-0.55$ \\
\hline a.Emotionalizing & 17 & 21.24 & 5.62 & 45 & 19.71 & 6.98 & $\mathrm{t}(1,60)=0.81$ \\
\hline b. Fantasizing & 17 & 22.94 & 5.58 & 45 & 25.89 & 8.03 & $\mathrm{t}(1,60)=-1.39$ \\
\hline DES/28 & 17 & 25.79 & 15.50 & 58 & 38.23 & 18.03 & $\mathrm{t}(1,73)=-2.58^{*}$ \\
\hline a. Absorption & 17 & 418.90 & 201.10 & 58 & 546.01 & 225.62 & $\mathrm{t}(1,73)=-2.09^{*}$ \\
\hline b. Diss. Amnesia & 17 & 123.82 & 116.76 & 58 & 175.06 & 143.11 & $\mathrm{t}(1,73)=-1.35$ \\
\hline c. Deper E Derea & 17 & 179.45 & 146.03 & 58 & 349.29 & 181.19 & $\mathrm{t}(1,73)=-3.54^{* *}$ \\
\hline SELF & 17 & 88.39 & 17.34 & 58 & 71.06 & 19.66 & $\mathrm{t}(1,73)=3,27^{* *}$ \\
\hline
\end{tabular}

Table 2. Differences between male and female respondents on alexithymia, dissociation and self $\left(^{*}: p<0.05,{ }^{* *}: p<0.01,{ }^{* * *}: p<0.001\right)$

Females scored significantly more alexithymic than men on the cognitive component, particularly on Identifying and Verbalizing emotions (on Analyzing the sexes did not differ significantly). Neither on the affective component nor on its subscales Emotionalizing and Fantasizing gender differences was significant. With the exception of the subscale 'Activities of Dissociated States', also called Dissociative amnesia, women scored significantly higher on all dissociation measures as well. Furthermore CSA women had a significantly lower self-concept. From the above it is concluded that that the impact of CSA is greater for women than for men.

\section{Discussion}

\subsection{Impact of CSA on alexithymia, dissociation and self}

Subjects in our sample have been victims of severe CSA and the results on alexithymia, dissociation, self and memory recovery confirm the notion that severe CSA has a devastating effect on psychological health in adulthood. The incidence of alexithymia $(40 \%)$ was found to be substantially higher than the statistics published in non-abused populations in various different countries (around 20\%; see the BVAQ description in the instruments part). Furthermore it was found that $47 \%$ of males and $78 \%$ of the females had average DES scores $>25$, indicating DID. Finally CSA respondents reported a negative self. The outcomes above can be criticized on a common problem with prevalence indices for psychological disorders, e.g. where the exact cut off value should be located to ensure a valid diagnosis of alexithymia, dissociation or self. To some extent cut off scores always remain arbitrary and subjective. Even when sensitivity and specificity requirements are fulfilled the choice of the criterion remains an arbitrary decision. Furthermore the reliability on the reported abuse characteristics, a common problem in all retrospective studies using self-report questionnaires, can be questioned as well. 


\subsection{Gender specific outcomes}

The impact for female victims was significantly stronger than for male victims (see Table 2). This result parallels the outcomes of gender differences in normal populations. Women generally have both stronger dissociative tendencies and a more negative self. However, in general men are more alexithymic and less emotional than women. Our results indicate the contrary, e.g. CSA women were found to be significantly more alexithymic than men, but only on the cognitive component (reduced Verbalizing and Identifying). The credibility issue, discussed in the introduction, and still associated with the feminine stereotype (hysterical, emotional, fantasy prone, liar, etc.) might be responsible for the highly impaired cognitive component in women, as not being taken seriously by expressing doubts on the credibility of their accounts, hampers the formation between the emotional experience and its cognitive labels. This invalidating environment where cries for help of the abused child are ignored or denied, often even by the mother, is described by Huber (1997) as one of the four factors associated with the development of DID. On the affective component (reduced Fantasizing and Emotionalizing) however, the sexes did not differ significantly from each other, which is remarkable as well because women usually are more emotional than men (Carpenter \& Addis). The reported gender differences cannot be attributed to particular abuse characteristics because the sexes didn't differ significantly on any characteristic (see Table 1). It should be noted that in one category, e.g. 'perpetrator', only t-tests where the father had been the perpetrator ( $29 \%$ for males, $40 \%$ for females) could be performed, as in all other cases one of the groups contained empty cells. The data on perpetrators suggest, that adult relatives (grandfather, uncle) and strangers more often abused girls, while older siblings and adults they knew well, other than relatives (teachers, priests, coaches in sport clubs, etc.), more often abused boys. As it is extremely difficult to escape abuse in invalidating environments if an adult relative is the perpetrator it might be that threatening, physical violence and other coercions employed by the perpetrator to enforce secrecy (don't tell anybody about our secret otherwise ...) have led to the reported higher impairment of the cognitive alexithymia component in combination with higher dissociation scores in female victims.

\subsection{Gender differences from a neurobiological perspective}

An alternative way of discussing the results is looking for neurobiological substrates explaining behavioural gender differences. Larger prefrontal lobe CSF volumes and smaller midsaggital area of the corpus callosum subregion 7 (splenium) were seen in both boys and girls with maltreated-related PTSD (De Bellis \& Keshavan, 2003). Subjects with PTSD did not show the normal age related increases in the area of the total corpus callosum and splenium. However this finding was more prominent in males with PTSD. Significant sex by group effects demonstrated smaller cerebral volumes and corpus callosum regions 1 (rostrum) and 6 (isthmus) in PTSD males and greater lateral ventricular volume increases in maltreated males with PTSD than maltreated females with PTSD. According to De Bellis and Keshavan their findings suggest that males are more vulnerable to the effects of severe stress in global brain structures than females. In the well-controlled, highly elegant study of De Bellis and Keshavan maltreated males with PTSD did show a trend towards reporting of more cluster $\mathrm{C}$ symptoms (e.g. avoidant and dissociative behaviors) than maltreated females with PTSD. The associated behavior includes efforts to avoid traumatic reminders, 
diminished interest in others, feelings of detachment, a restricted range of affect, and dissociation. Emotional numbing and diminished interest in others, particularly during development, may result in lack of empathy and an increased risk for anti-social behaviors and externalizing behaviors.

\subsection{Incongruence between what is expected from the neurobiological substrate on gender differences in symptomatology and its behavioral manifestation}

However, our results on gender differences are the opposite of what would be expected from a neurobiological perspective. How can this be explained? De Bellis and Keshavan note that their cross-sectional investigation does not imply causation. Neither does our investigation. It is not possible to disentangle whether observed sex differences are the consequence of the stress and trauma or a preexisting risk factor for the development of a disorder. It might well be that the male subjects in our sample did not have a preexisting risk factor but instead a preexisting protective buffer (low levels of neuroticism) against the development of a specific disorder. In this context it should be noted that only seventeen male respondents were willing to volunteer in our research. They were hard to find. There is still a 'taboo' on talking about male sexual abuse, in particular because it concerned same-sex relationships, which could make others think the victim consented to the abuse and is homosexual. It might well be that the male respondents who were willing to share their experiences with others were the stronger ones with more healthy personality profiles (lack of neuroticism), who were better equipped to cope with the adverse effects of CSA.

Even though our findings are not in agreement with what could be expected from a neurobiological point of view they do correspond to the general notion that women display a higher level of symptom reporting than men (Wool \& Barsky, 1994; Kroenke \& Spitzer, 1998). However it should be noted as well that one of the more controversial issues in terms of mental disorder diagnoses has been their differential sex prevalence (Hartung \& Widiger, 1998). The point to be made is that it cannot be denied that what is suggested by neurobiological studies, e.g. that males are more vulnerable to the effects of severe stress in global brain structures than females, does not always correspond to what has been reported on the behavioral level in symptomatology. Hence, it remains striking that women who on the neurobiological level are assumed to be less vulnerable to stress (the stronger sex) have on the behavioral level both a reputation for and do show the symptoms of vulnerability to stress in a wide array of activities (the weaker sex). It might well be that the immensely popular brain model in contemporary academic science also has its flaws and does not account yet for the more phenomenological (how people experience events and impressions) aspects of human existence. Anyway we sincerely hope that our research with all its weaknesses and limitations is challenging enough to stimulate future research on the virgin territory of gender differences in CSA.

\section{Conclusions}

CSA-victims display: 1) a high prevalence of alexithymia (40\% as opposed to $20 \%$, reported in general populations), 2) high dissociation scores (> 25 on the average DES), indicative of Dissociative Identity Disorder, and 3) a negative self. 
The impact of CSA on alexithymia, dissociation and self is significantly stronger for women than for men, and cannot be attributed to differences in abuse characteristics and age.

\section{References}

Albach, F. \& Everaerd, W. (1992). Posttraumatic stress symptoms in victims of childhood incest. Psychotherapy and Psychosomatics, Vol.57, pp. 143-151

Albach, F. (1993). Freud's Verleidingstheorie: Incest, trauma en hysterie [Freud's seduction theory: Incest, trauma and hysteria]. PhD thesis, University of Amsterdam, Stichting Petra, ISBN 90-74214-04-5, Middelburg, The Netherlands

Albach, F.; Moormann, P.P. \& Bermond, B. (1996). Memory recovery of childhood sexual abuse. Dissociation, Vol.9, pp. 258-269

Bakan, D. (1966). The duality of human existence, Beacon Press, Boston, MA

Bauer, H.; Moormann, P.P. \& Hagtvet, K. (1992). Anxiety and perceived development of self at different stages of poly-hard-drug addicts, In: Advances in in Tests Anxiety Research (Vol. 7), K.A. Hagtvet (Ed.), 189-205, Swets \& Zeitlinger, Lisse

Bailey, P.E. \& Henry J.D. (2007). Alexithymia, somatisation and negative affect in a community sample. Psychiatry Research, Vol.150, pp. 13-20

Berenbaum, H. (1996). Childhood abuse, alexithymia and personality disorder. Journal of Psychosomatic Research, Vol.41, pp. 585-595

Berenbaum, H. \& James, T. (1994). Correlates and retrospectively reported antecedents of alexithymia. Psychosomatic Medicine, Vol.56, pp. 353-359

Bermond, B. \& Vorst, H. (1993). The Bermond Vorst Alexithymia Questionnaire. Unpublished internal report, Deparment of Psychology, University of Amsterdam.

Bermond, B.; Clayton, K.; Liberova, A.; Luminet, O.; Maruszewski, T.; Ricci Bitti, P. E.; Rime, B.; Vorst, H.; Wagner, H. \& Wicherts, J. ( 2007). A cognitive and an affective dimension of alexithymia in six languages and seven populations. Cognitions and Emotions, Vol.21, Nr.5, pp. 1125-1136

Bermond, B.; Moormann, P.P.; Albach, F. \& Dijke, A. van (2008). Impact of severe childhood sexual abuse on the development of alexithymia in adulthood. Psychotherapy and Psychosomatics, Vol.77, 260-261

Bernstein, E.M. \& Putnam, F.W. (1986). Development, reliability, and validity of a dissociation scale. Journal of Nervous and Mental Disease, Vol.174, pp. 727-735

Birnbaum, B. (1915). Die sexuellen Falschanschuldigungen der Hysterischen. [The false sexual accusations of the hysterics]. Gross-Archiv, Band 64

Boon, S. \& Draijer, N. (1993). Multiple personality disorder in the Netherlands: A study on reliability and validity of the diagnosis, Zwets \& Zeitlinger, Lisse

Butler, L. D. \& Nolen-Hoeksema, S. (1994). Gender differences in responses to depressed mood in a college sample. Sex Roles, Vol.30, pp. 5-6

Carmen, E. H.; Rieker, P. P. \& Mills, T. (1984). Victims of violence and psychiatric illness. American Journal of Psychiatry, Vol.141, pp. 378-383

Carpenter, K.M. \& Addis, M.E. (2000). Alexithymia, gender, and responses to depressive symptoms. Sex Roles, Vol.43, pp. 629-644

Ceci, S.J. \& Loftus, E.F. (1994). 'Memory work': A royal road to false memories? Applied Cognitive Psychology, Vol.8, pp. 351-364

Chu, J.A. \& Dill, L.D. (1990). Dissociative symptoms in relation to childhood physical and sexual abuse. American Journal of Psychiatry, Vol.147, pp. 887-892 
Cloitre, M.; Scarvalone, P. \& Difede, J. (1997). Posttraumatic stress disorder, self- and interpersonal dysfunction among sexually retraumatized women. Journal of Traumatic Stress, Vol.10, pp. 437-442

Coons, P. M. (1996): The dissociative disorders. Rarely considered and underdiagnosed. Psychiatric Clinics of North America, Vol.21, pp. 637-648

Crombag, H.F.M. \& Merckelbach, H.L.G.J. (1996). Hervonden herinneringen en andere misverstanden [Recovered memories and other misapprehensions], Contact, Amsterdam

De Bellis M.D. \& Keshavan, M.S. (2003). Sex differences in brain maturation in maltreatment-related pediatric posttraumatic stress disorder. Neuroscience and Biobehavioral Reviews, Vol.27, pp. 103-117

Dhaliwal, G.K.; Gauzas, L.; Antonowicz, D.H. \& Ross, R.R. (1996). Adult male survivors of child sexual abuse: Prevalence, sexual abuse characteristics and long term effects. Clinical Psychology Review, Vol.16, pp. 619-639

Eliot, D.M. \& Briere, J. (1992). Sexual abuse trauma among professional women: Validating the Symptom Trauma Checklist-40 (TSC 40). Child abuse and Neglect, Vol.16, pp. 391-398

Elzinga, B.; Bermond, B. \& Van Dyck, R. (2002). The relationship between dissociative proneness and alexithymia. Psychotherapy and Psychosomatics, Vol.71, pp. 104-111

Ensink, B.J. (1992). Confusing realities: A study on child sexual abuse and psychiatric symptoms, Ph.D. thesis, VU University Press, Amsterdam

Feiring, C.; Taska L. \& Lewis, M. (1999). Age and gender differences in children's and adolescent's adaptation to sexual abuse. Child abuse and Neglect, Vol.23, pp. 115-128

Finkelhor, D. \& Browne, A. (1985). The traumatic impact of child sexual abuse: A conceptualization. American Journal of Orthopsychiatry, Vol.55, 530-541

Frewen, P.A.; Dozois, D.J.A.; Neufeld, R.W. \& Lanius., R.A. (2008). Meta-analysis of alexithymia in Post Traumatic Stress Disorder. Journal of Traumatic Stress, Vol.21, pp. 243-246

Garnefski, N. \& Arends, E. (1998). Sexual abuse and adolescent maladjustment: Differences between male and female victims. Journal of Adolescence, Vol.21, pp. 99-107

Garnier, P. (1903). Les hystériques accusatrices [The accusing hysterics]. Annales d'hygiène publique et de médicine légale, troisième série, tome L., J-B Ballière et fils, Paris

Grabe, H. J.; Rainermann, S.; Spitzer, C.; Gansicke, M. \& Freyberger, H.J. (2000). The relationship between dimensions of alexithymia and dissociation. Psychotherapy and Psychosomatics, Vol.69, pp. 128-131

Gold, S.N.; Hill, E.L.; Swingle, J.M. \& Elfant, S. A. (1999). Relationship between childhood abuse characteristics and dissociation among women in therapy. Journal of Family Violence, Vol.14, pp. 157-17

Hartung, C.M. \& Widiger, T.A. (1998). Gender differences in the diagnosis of mental disorders: Conclusions and controversies of the DSM-IV. Psychological Bulletin, Vol.123, Nr.30, pp. 260-278

Honkalampi, K,; Hintikka, J.; Taskanen, A.; Lehtonen, J. \& Viinamki, H. (2000). Depression is strongly associated with alexithymia in the general population. Journal of Psychosomatic Research, Vol.48, pp. 99-104

Herman, J.L. (1981). Father-daughter incest, Harvard University Press, Cambridge

Horowitz, M.J. (1976). Stress response syndromes (2nd. Ed.), Jason Aronson, Northvale, NJ 
Huber, M. (1997). Meervoudige persoonlijkheden: Een handboek voor overlevenden van extreme geweld [Multiple personalities: A manual for survivors of extreme violence, translated from German, first published in 1995 by Fischer Tachenbuch Verlag GmbH, Frankfurt am Main], Wereldbibliotheek, Amsterdam

Hunter, M. (1990). Abused boys: The neglected victims of sexual abuse, Lexington Books \& D. C. Health and Company, Lexington

Hyer, L.; Woods, G.; Summers, M.N.; Boudewyns, P. \& Harrison, W.R. (1990). Alexithymia among Vietnam veterans with Post Traumatic Stress Disorder. Journal of Clinical Psychiatry, Vol.51, pp. 243-246

Irwin, H.J. \& Melbin-Helberg, E.B. (1997). Alexithymia and dissociative tendencies. Journal of Clinical Psychology, Vol.53, pp. 159-166

James, W. (1890). Principles of Psychology, Holt, New York

Janet, P. (1889). L'automatisme psychologique [The psychological automatism], Félix Alcan, Paris

Janoff-Bulman, B. \& Frieze, I. H. (1983). A theoretical perspective for understanding reactions to victimization. Journal of Social Issues, Vol.39, pp. 1-17

Kirby, J.S.; Chu, J.A. \& Dill, D.L. (1993). Correlates of dissociative symptomatology in patients with physical and sexual abuse histories. Comprehensive Psychiatry, Vol.34, pp. 258-263

Kisiel, C.L.L. \& Lyons, S.J. (2001). Dissociation as a mediator of psychopathology among sexually abused children and adolescents. American Journal of Psychiatry, Vol.158, pp. 1034-1039

Kluft, R.P. (1996). Dissociative Identity Disorder, In: Handbook of Dissociation: Theoretical, empirical and clinical perspectives, L.K. Michelson \& W.J. Ray (Eds.), 337-366, Plenum Press, New York

Kohn, A. (1987). Shattered innocence. Psychology Today, Vol.21, 54-58

Kooiman, C.G.; Rees Vellinga, S van; Spinhoven, P., Draijer, N.; Trijsburg, R.W \& Rooijmans, H.G.M. (2004). Childhood adversities as risk factors for alexithymia and other aspects of affect dysregulation in adulthood. Psychotherapy \& Psychosomatics, Vol.73, pp. 107-116

Kroenke, K. \& Spitzer, R.L. (1998). Gender differences in reporting of physical and somatoform symptoms. Psychosomatic Medicine, Vol.60, pp. 150-155

Krystal, H. (1988). Integration and self-healing: Affect, trauma and alexithymia, Analytic Press, Hillsdale, NY

Kuhn, J.A.; Arellano, C.M. \& Chavez, E.L. (1998). Correlates of sexual assault in MexicanAmerican and White non-Hispanic adolescent males. Violence and Victims, Vol.13, pp. $11-20$

Loas, G.; Fremaux, D.; Otmani, O. \& Verrier, A. (1995). Prevalence of alexithymia in a general population. Study in 183 "normal" subjects and in 263 students. Annales médico-psychologiques, Vol.153, Nr.5, pp. 355-357

Loftus, E.F. (1993). The reality of repressed memories. American Psychologist, Vol.48, pp. 518537

Loftus, E.F. (1997). Creating false memories: Researchers are showing how suggestion and imagination can create "memories" of events that did not actually occur. Scientific American, September, pp. 50-55 
Maccoby, E. (1990). Gender and relationships: A developmental account. American Psychologist, Vol. 45, pp. 513-520

Markus, H. \& Oyserman, D. (1989). Gender and thought: The role of the self-concept, In: Gender and thought, M. Crawford \& M. Hamilton (Ed.), 100-127, Springer-Verlag, New York

Myers, M. F. (1989). Men sexually assaulted as adults and sexually abused as boys. Archives of Sexual Behaviour, Vol.18, pp. 203-215

Modestine, J. ; Furrer, R. \& Malti, T. (2005). Different traumatic experiences are associated with different pathologies. Psychiatry Quaterly, Vol.76, pp. 19-32

Moody, W.C. (1999). Male child sexual abuse. Journal of Pediatric Health Care, Vol.13, Nr.3, pp. 112-119

Moormann, P.P. \& Duijkers, T.J. (1984). Het psychologische moeras van drugverslaving [The psychological morass of drug addiction], Internal report LPR-PP: 84-061, Department of Psychology, Leiden University, The Netherlands

Moormann, P.P., Cocq van Delwijnen, H. de, Wessel, K. van, \& Bauer, H. (1989). Personality characteristics of drug addicts in the Netherlands, Internal report LPR-PP: 02-89, Department of Psychology, Leiden University, The Netherlands

Moormann, P.P.; Bermond, B.; Albach, F. \& Dorp, I. van (1997). The etiology of alexithymia from the perspective of childhood sexual abuse, In: The (non)expression of emotions in health and disease, Ad Vingerhoets, Frans van Bussel, \& Jan Boelhouwer (Eds.), 139153, Tilburg University Press, Tilburg

Moormann, P.P.; Bermond, B. \& Albach, F. (2004). The Reality Escape Model: The intricate relation between alexithymia, dissociation, and anesthesia in victims of child sexual abuse, In: Emotional Expression and Health, Ivan Nyklicek, Ad Vingerhoets, \& Lydia Temoshok (Eds), 82-98, Brunner Routledge, Hove

Moormann, P.P.; Bermond, B.; Vorst, H.C.M.; Bloemendaal, A.; Teijn, S. \& Rood, L. (2008). New avenues in alexithymia research: The creation of alexithymia types. In: Emotion Regulation: Conceptual and Clinical Issues, Johan Denollet, Ivan Nyklicek, \& Adrianus Vingerhoets (Eds.), 27-42, Springer, New York

Paivio, S.C. \& McCulloch, C.R. (2004). Alexithymia as a mediator between childhood trauma and self-injurious behaviors. Child Abuse and Neglect, Vol.28, pp. 339-354

Parker, J.D.A.; Taylor, G.J. \& Bagby, M. (1989). The alexithymia construct: Relationship with sociodemographic variables and intelligence. Comprehensive Psychiatry, Vol.30, pp. 434-444.

Putnam, F.W. (1993). Dissociative disorders in children: behavioural profiles and problems. Child abuse and Neglect, Vol.17, pp. 39-45

Putnam F.W.; Carlson E.B.; Ross, C.A.; Anderson, G.; Clark P.; Torem; M., Bowman, E.S.; Coons, P.; Chu, J.A.; Dill, D.L.; Loewenstein, R.J. \& Braun, B.G. (1996). Patterns of dissociation in clinical and non clinical samples. Journal of Nervous and Mental Disorders, Vol.184, pp. 673-679

Rogers, C.N. \& Terry, T. (1984). Clinical interventions with boy victims of sexual abuse, In: Victims of sexual aggression: Treatment of children, women, and men, I.R. Stuart \& J.G. Greer (Eds.), 91-104, Van Nostrand Reinhold, New York

Ross, C.A. (1996). History, phenomenology and epidemiology of dissociative disorders, In: Handbook of dissociation, L.K. Michelson \& W.J. Ray (Eds), 3-24, Plenum Press, New York 
Ross, C.A.; Ellason, J.W. \& Anderson, G. (1995). A factor analysis of the Dissociative Experience Scale (DES) in dissociative identity disorder. Dissociation, Vol.8, pp. 229235

Russell, D.E.H. (1986). The secret trauma: Incest in the lives of girls and women. Basic Books, New York

Sher, D. \& Twaite, J.A. (1999). The relationship between child sexual abuse and alexithymic symptoms in a population of recovering adult substance abusers. Journal of Child Sexual Abuse, Vol.8, pp. 25-40

Sifneos, P.E. (1973). The prevalence of alexithymic characteristics in psychosomatic patients. Psychotherapy and Psychosomatics, Vol.22, pp. 250-262.

Sifneos, P.E. (1975). Problems of psychotherapy of patients with alexithymic characteristics and physical disease. Psychotherapy and Psychosomatics, Vol.26, pp. 65-70

Taylor, G.J.; Bagby, R.M. \& Parker, D.A. (1997). Disorders of affect regulation: Alexithymia in medical and psychiatric illness, Cambridge University Press, Cambridge

Thomas, R.K.; Krystal, J.H.; Giller, E.L.; Frank, J. \& Dan., E. (1992). Alexithymia as a predictor response in post traumatic stress disorder. Journal of traumatic stress, Vol.5, pp. 563- 573

Tzeng, O.C.S. \& Schwarzin, H.I. (1990). Gender and race differences in child sexual abuse correlates. International Journal of Intercultural Relations, Vol.14, pp. 135-161

Vorst, H.C.M. \& Bermond, B. (2001). Validity and reliability of the Bermond-Vorst Alexithymia Questionnaire. Personality and Individual Differences, Vol.30, pp. 413-434

Walker, J.L.; Carey, P.D.; Mohr; N.; Stein, D.J. \& Seedat, S. (2004). Gender differences in the prevalence of child sexual abuse and in the development of pediatric PTSD. Archive of women's mental health, Vol.7, Nr.2, pp. 111-121.

Wool, C.A. \& Barsky, A.J. (1994). Do women somatize more than men? Gender differences in somatization. Psychosomatics, Vol.35, pp. 445-452

Yapko, M.D. (1994). Suggestions of abuse: True and false memories of childhood sexual trauma, Simon \& Schuster, New York

Zeitlin, S.B.; McNally, R.J. \& Cassiday, K.L. (1993). Alexithymia in victims of sexual assault: An effect of repeated traumatization? American Journal of Psychiatry, Vol.150, pp. 661-663

Zlotnick, C.; Shea, M.T.; Pearlstein, T.; Simpson, E.; Costello, E. \& Begin, A. (1996). The relationship between dissociative symptoms, alexithymia, impulsivity, sexual abuse, and self-mutulation. Comprehensive Psychiatry, Vol.37, pp. 12-16

Zlotnick, C.; Mattia, J. I. \& Zimmermann, M. (2001). The relationship between post traumatic stress disorder, childhood trauma and alexithymia in an outpatient sample. Journal of Traumatic Stress, Vol.14, pp. 177-187 


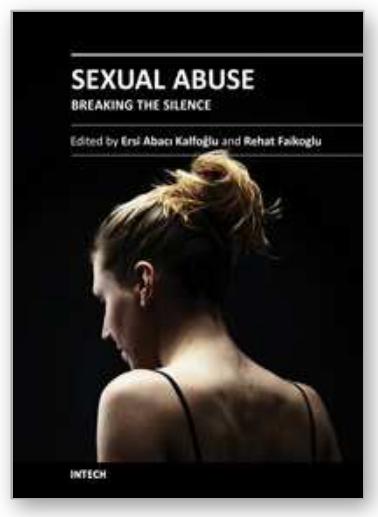

\author{
Sexual Abuse - Breaking the Silence \\ Edited by Dr. Ersi Abaci Kalfoğlu
}

ISBN 978-953-51-0425-4

Hard cover, 238 pages

Publisher InTech

Published online 23, March, 2012

Published in print edition March, 2012

Sexual assault can be considered as expression of aggression through sex. This, in turn, can have serious negative effects on a survivor's social and occupational functioning. This book has been organized towards that specific approach, by compiling the scientific work of very well-known scientists from all over the world. The psychological victimization of sexual assault, the physiological aspect of sexual abuse and the different attitudes in coping with sexual assault based on different cultural backgrounds are analyzed. Having in mind that one solution may not necessarily be suitable for all cases, we hope that this book will open a debate on sexual assault for future practice and policy and that it will be a step forward to 'break the silence'.

\title{
How to reference
}

In order to correctly reference this scholarly work, feel free to copy and paste the following:

Peter Paul Moormann, Francine Albach, Bob Bermond, Annemieke van Dijke, Jakob de Jong, Jaco Wineke, Kalliopi Metta and Argyro Karanafti (2012). Gender Differences in the Impact of Child Sexual Abuse on Alexithymia, Dissociation and Self, Sexual Abuse - Breaking the Silence, Dr. Ersi Abaci Kalfoğlu (Ed.), ISBN: 978-953-51-0425-4, InTech, Available from: http://www.intechopen.com/books/sexual-abuse-breaking-thesilence/gender-differences-in-the-impact-of-childhood-sexual-abuse-on-alexithymia-dissociation-and-self

\section{INTECH}

open science | open minds

\section{InTech Europe}

University Campus STeP Ri

Slavka Krautzeka 83/A

51000 Rijeka, Croatia

Phone: +385 (51) 770447

Fax: +385 (51) 686166

www.intechopen.com

\section{InTech China}

Unit 405, Office Block, Hotel Equatorial Shanghai

No.65, Yan An Road (West), Shanghai, 200040, China

中国上海市延安西路65号上海国际贵都大饭店办公楼 405 单元

Phone: +86-21-62489820

Fax: +86-21-62489821 
(C) 2012 The Author(s). Licensee IntechOpen. This is an open access article distributed under the terms of the Creative Commons Attribution 3.0 License, which permits unrestricted use, distribution, and reproduction in any medium, provided the original work is properly cited. 